\title{
Social Context, Self-perceptions and Student Engagement: A SEM investigation of the self- system model of motivational development (SSMMD)
}

\section{Serge Dupont ${ }^{1}$, Benoît Galand ${ }^{1}$, Frédéric Nils ${ }^{2}$, and Virginie Hospel ${ }^{1}$}

\begin{tabular}{c}
\hline${ }^{1}$ Université Catholique de Louvain \\
${ }^{2}$ Facultés Universitaires Saint-Louis \\
\hline
\end{tabular}

\section{Belgium}

Correspondence: Dupont Serge. Place du Cardinal Mercier, 10, B-1348 Louvain-la-Neuve, Belgium. E-mail: s.dupont@uclouvain.be

(C) Education \& Psychology I+D+i and Ilustre Colegio Oficial de Psicología de Andalucía Oriental (Spain) 


\begin{abstract}
Introduction. The present study aimed to test a theoretically-based model (the self-system model of motivational development) including at the same time the extent to which the social context provides structure, warmth and autonomy support, the students' perceived autonomy, relatedness and competence, and behavioral, cognitive and emotional student engagement.

Method. Three hundred and thirty one participants attending the last year at the university completed a self-reported questionnaire tapping the targeted variables. SEM analyses were used to test our hypotheses.

Results. Results revealed that each dimension of the social context was associated with the corresponding self-perception variables which, in turn, predicted greater behavioral, cognitive and emotional engagement. Cognitive engagement was directly predicted by the three selfperception variables, and indirectly by an autonomy supportive social context. Structured social context was indirectly associated, through perceived competence, with behavioral and emotional engagement.

Discussion and Conclusion. Two underlying assumptions of the SSMMD (and more broadly of the SDT) were supported by the results of this study - the three dimensions of social context have specific effects on self-perception variables and these perceptions are mediators of the relationship between context and student engagement - one was not - the three selfperception variables do not have a direct impact on the dimensions of student engagement.
\end{abstract}

Keywords: Social context; Self-perception; Student engagement

Received: 09/03/13 Initial acceptance: 10/05/13 Final acceptance: 03/17/14 


\section{Contexto social, autopercepción y compromiso del Estudiante: Una investigación SIM del Modelo de auto-sistema de desarrollo motivacional (ASDM) Resumen}

Introducción. El presente estudio tuvo como objetivo probar un modelo (basado en teoría del- auto-sistema de desarrollo motivacional que incluye, al mismo tiempo, la medida en que el contexto social proporciona la estructura de soporte, calidez y autonomía, la percepción de autonomía de los alumnos, la relación entre la competencia conductual-cognitiva y el compromiso emocional de los estudiantes.

Método. Trescientos treinta y un participantes en el último año en la universidad completaron un cuestionario de auto-informe sobre las variables específicas. Se utilizaron Análisis SEM para probar nuestras hipótesis.

Resultados. Los resultados revelaron que cada dimensión del contexto social se asoció con las variables autopercepción correspondientes que, a su vez, predice un mayor compromiso conductual, cognitivo y emocional. El compromiso cognitivo se predijo directamente por las tres variables de la auto-percepción e, indirectamente por un contexto social que apoye la autonomía. El contexto social estructurado se asocia indirectamente, a través de la percepción de competencia, con el compromiso conductual y emocional.

Discusión y Conclusión. Dos supuestos subyacentes de la SSMMD (y más, en general, del SDT) fueron apoyados por los resultados de este estudio. Las tres dimensiones del contexto social tienen efectos específicos sobre las variables de auto-percepción y estas percepciones son mediadores de la relación entre el contexto y el compromiso del estudiante. Las tres variables de autopercepción no tienen un impacto directo sobre las dimensiones de la participación estudiantil.

Palabras clave: contexto social, auto-percepción, compromiso del estudiante 


\section{Introduction}

Student engagement in schooling is a major concern for many teachers, parents and politicians. Scholars defined student engagement as "The quality of a student's connection or involvement with the endeavor of schooling and hence with the people, activities, goals, values, and place that compose it" (Skinner, Kindermann \& Furrer, 2009, p. 494). It essentially concerns the way students connect themselves with a learning task. Student engagement is an important educational outcome in itself, as it reflects students' positive functioning, but it is further important because it is a key predictor of students' grades and achievement (Furrer \& Skinner, 2003; Reeve, Jang, Carrell, Jeon, \& Barch, 2004), persistence (Appleton, Christensen, Kim, \& Reschly, 2006), well-being (Brault-Lobé \& Dubé, 2010), drop-out (Archambault, Janosz, Fallu, \& Pagani, 2009) and timely completion of the final graduate dissertation (Dupont, Meert, Galand, \& Nils, 2013).

A consensus is emerging among scholars to consider that at least three dimensions of student engagement can be disentangled: emotional, cognitive and behavioral (Appleton et al., 2008; Fredricks et al., 2004; Reeve, 2012). Emotional engagement refers to the students' affective reactions when they face an academic task (Pekrun, 2006; Skinner \& Belmont, 1993). Cognitive engagement refers to the use of surface- and deep-processing strategies and self-regulation strategies (Marton \& Säljö, 1997; Miller, Greene, Montalvo, Ravindran, \& Nichols, 1996). Finally, behavioral engagement refers to the students' effort and persistence during the initiation and execution of a learning task (Birch \& Ladd, 1997; Finn, Pannozzo, \& Voelkl, 1995; Skinner, Kindermann \& Furrer, 2009).

To understand the processes leading to student engagement or disengagement, several theoretical models have been proposed (Christenson, Reschly, \& Wylie, 2012). The selfsystem model of motivational development (SSMMD), developed by Skinner and colleagues (Skinner \& Belmont, 1993; Skinner, Furrer, Marchand, \& Kindermann, 2008) from the work of Connell and Wellborn (1991) and the self-determination theory (Ryan \& Deci, 1985), is actually one of the most prominent models. This model integrates contextual (i.e. the extent to which the social context provides students with warmth, structure, and autonomy support) and self-perception (i.e. the students' perceived competence, autonomy and relatedness) variables to describe the processes that promote or undermine individual's engagement within a particular activity (see figure 1). 


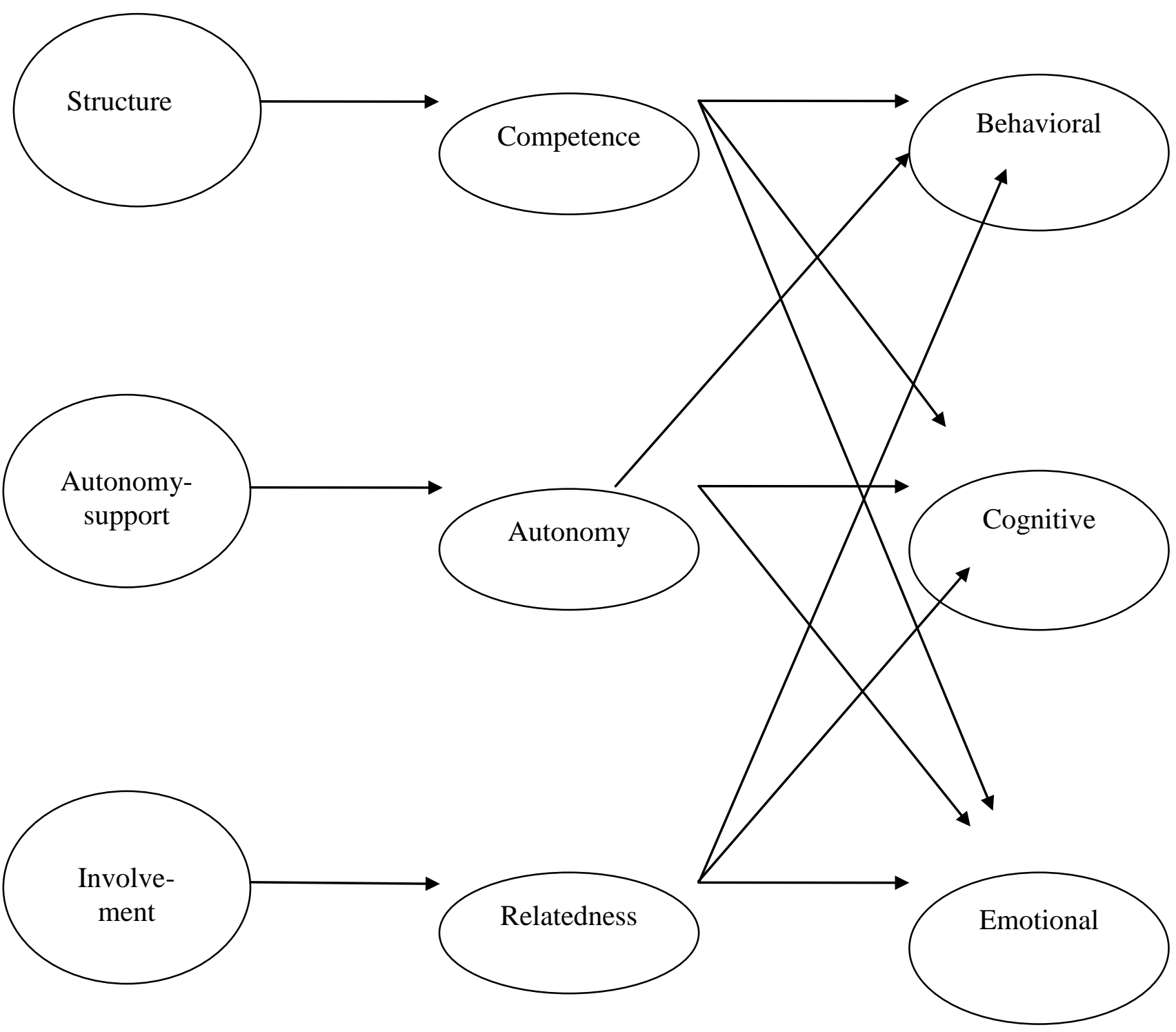

Figure 1. Hypothesized model of the relations between the social context, self-perceptions and student engagement

If some parts of the SSMMD had received empirical support, almost no study had included the complete set of variables comprised in the model and tested the model as a whole. Most available studies focused on one or two dimensions of the social context, of self- 
perceptions and/or of engagement, and analyzed some specific associations within the model rather than the fit of the model itself (e.g. Connell et al., 1994; Furrer \& Skinner, 2003; Skinner et al., 2008). However, as mentioned above, engagement is notoriously a multidimensional concept, including at least an emotional, a cognitive and a behavioral component (Reeve, 2012). Besides, three dimensions of the social context are identified in the SSMMD - structure, autonomy support, and involvement, each one being hypothesized to have independent effect on one of three self-perceptions. Assessing some relationships without taking into account the other dimensions of the model could results in spurious associations and do not allow a real test of the theoretical model.

Therefore, the aim of the present study is to overcome some of those limitations by investigating the fit between the whole patterns of relationships postulated by the SSMMD and observed data, through structural equation analyses. The next sections of the paper present the theoretical assumptions of the SSMMD, a description of its components, as well as a brief review of its empirical supporting evidence.

\section{Theoretical assumptions of the SSMMD}

The SSMMD is mainly a modelization of the self-determination theory (SDT; Deci \& Ryan, 1985; Deci \& Ryan, 2000). According to the SDT, humans have three basic psychological needs: feeling competent, autonomous and in relationship. Based on this premise, the SSMMD posits that opportunities to experience autonomy, competence and relatedness are essential for optimal student engagement. When the social context (e.g. teacher and peers) is supportive, the basic needs are fulfilled, so the level of engagement in learning activities ultimately increases (Connell \& Wellborn, 1991; Skinner et al., 2008). Conversely, when the social context is not nurturing, the basic needs are not fulfilled, and the level of engagement is undermined.

According to the SSMMD, specific dimensions of the social context foster the fulfillment of corresponding basic psychological needs (Skinner \& Belmont, 1993). In particular, students' need for competence is satisfied when the environment provides structure; their need for autonomy is fulfilled when the environment leaves them responsibilities and choices; and their need for relatedness is fulfilled when they experience concern and affection from the environment. So this model does not posit crossed associations between dimensions of social context and self-perceptions variables (Connell \& Wellborn, 1991). Within this theoretical 
framework, the most proximal predictors of student engagement are perceived autonomy, competence and relatedness (Skinner \& Belmont, 1993; Skinner et al., 2008) and each selfperception is considered as having a unique and direct effect on engagement variables (Connell \& Wellborn, 1991; Furrer \& Skinner, 2003). In addition, the self-perceptions also mediate the relationships between the social context and student engagement (Connell \& Wellborn, 1991; Skinner et al., 2008). In the following sections, we will review studies that already tested some of the relationships proposed in the SSMMD.

\section{Social context and self-perceptions}

Three dimensions of the social context are identified in the SSMMD: autonomy support, structure, and involvement. Autonomy support provided by teachers, i.e. opportunities for self-choice, shared decision, initiative and avoidance of external control strategies such as grades and rewards, was found to increase students' perceived autonomy, classroom engagement, creativity and academic achievement (Reeve et al., 2004; Ryan \& Grolnick, 1986; Vallerand \& Bissonnette, 1992; Vansteenkiste et al., 2004; Williams \& Deci, 1996). Structure provided by teachers, i.e. clear information and expectations, cognitive guidance, and constructive, timely and informative feedback (Skinner \& Belmont, 1993; Skinner, ZimmerGembeck, \& Connell, 1998) was found to positively predict students' perceived competence and behavioral engagement (Skinner \& Belmont, 1993; Skinner et al., 2008). Involvement provided by teachers, i.e. time and energy devoted to interactions with students, care and concern, warmth and affection, was found to be positively associated with student perceived relatedness, happiness and enthusiasm in class (Birch \& Ladd, 1997; Murray \& Greenberg, 2000; Reeve, 2002; Wentzel, 1997).

However, a longitudinal study by Roeser, Midgley and Urban (1996) showed that, contrary to SSMMD's theoretical assumptions, provision of structure was related to students' perceived relatedness. In this case, there was no correspondence between the dimension of the social context and the fulfillment of a basic psychological need. Moreover, another study found that involvement was associated with perceived relatedness, but also with perceived competence and autonomy (Taylor \& Ntoumanis, 2007). This result suggests that crossed relationships between dimensions of the social context and self-perception can also be observed when all the dimensions are considered at the same time. In addition, structure and autonomy support were found to be highly correlated, and also associated with self-regulation strategies, but when these two dimensions were both included in a regression to predict self-regulation 
strategies, the effect of autonomy support on self-regulation disappeared (Sierens et al., 2009). As few studies have investigated the concurrent impact of the three dimensions of the social context on engagement, this last result suggests that the effect of a dimension of the social context found in some studies reviewed above could be better explained by another dimension of the social context.

\section{Self-perceptions and engagement}

According to the SSMMD, self-perceptions are durable personal resources that students construct over time in response to their interactions with the social environment; they are organized around the three basic psychological needs, i.e. autonomy, competence and relatedness. These self-perceptions are considered as the most proximal predictors of student engagement, as well as the mediators of the relationships between the social context and student engagement (Connell \& Wellborn, 1991; Skinner \& Belmont, 1993; Skinner et al., 2008).

Perceived autonomy refers to the individual's need for action that emanates from oneself, rather than being controlled by others. According to SDT, it is expressed by feeling of self-determination and personal interest when the student undertakes an activity (Deci \& Ryan, 1985). Competence refers to the individual's need to experience oneself as competent when interacting with the environment (Wigfield, Eccles, Schiefele, Roeser, \& Davis-Kean, 2006). It reflects the beliefs that students have about their ability to successfully achieve a learning task (Bandura, 1997). Relatedness refers to the basic need of being connected to others, accepted and valued by them. The core idea is that a feeling of belongingness and attachment allows people to explore and to engage constructively in activities and interactions with others (Baumeister \& Leary, 1995; Bowlby, 1969). Numerous studies have found feelings of autonomy, competence and relatedness were positively associated with cognitive, emotional, behavioral engagement in academic tasks (e.g. Bandura, 1991; Benware \& Deci, 1984; Connell \& Wellborn, 1991; Gaertner \& Dovidio, 2000; Goodenow, 1993; Furrer \& Skinner, 2003; Haussman, Schofield, \& Woods, 2007; Lam, Wong, Yang, \& Liu, 2012; Phan, 2007, 2009; Pintrich \& De Groot, 1990; Schunk, Pintrich, \& Meece, 2008; Skinner, Wellborn, \& Connell, 1990; Reeve \& Tseng, 2011; Vallerand, Fortier, \& Guay, 1997).

According to the SDT, these needs, that are complementary and highly correlated (Koestner, Losier, Vallerand, \& Carducci, 1996; Sheldon \& Bettencourt, 2002), still have unique and independent effects on engagement (Baard, Deci \& Ryan, 2004). However, most 
studies using the SSMMD framework did not considered the three self-perceptions simultaneously, so their unique effects on emotional, cognitive and behavioral engagement have not been clearly documented yet. For example, Furrer and Skinner (2003) concluded from their research that the perception of relatedness is a unique predictor of emotional and behavioral engagements. In their analyses, the authors have, in fact, controlled the impact of perceived competence on these dependent variables, but they did not control for perceived autonomy. Alternative hypotheses are that some self-perceptions are more important for some components of engagement or that some self-perceptions have a broader impact than others on the three components of engagement.

Regarding the mediation effect of self-perceptions between social context and engagement, divergent results have been found. In two studies, perceived autonomy mediated the relationship between autonomy support and us of deep-processing strategies (Vansteenkiste, Simons, Lens, Soenens, \& Matos, 2005; Vansteenkiste et al., 2004). In another study, perceived competence mediated the effect of structure and use of self-regulation strategies (Sierens et al., 2009). Yet in another study, perceived relatedness partially mediated the relationship between structure and positive emotions (Roeser et al., 1996). In addition, studies have shown that perceived competence was a meditator of the relationship between social context and student engagement (Connell, Halpern-Felsher, Clifford, Crichlow \& Usinger 1995; Skinner et al., 2008). Perceived relatedness is also a mediator of the relationship between social context and student engagement (Connell et al., 1995; Skinner et al., 2008). To add to this confusion, the SSMMD do not specify if the mediations are supposed to be total or partial.

\section{Aims of the study}

The aim of this study was to overcome a piecemeal approach to SSMMD by testing the three underlying assumptions of this model: (a) the specificity of the corresponding relations between dimensions of social context and self-perceptions (i.e. no crossed relations), (b) the independent contribution of each self-perception to the three components of engagement, and (c) the total mediation effect of self-perceptions in the relation between social context and engagement. We choose to conduct our study among university students, with final graduate dissertation offering a distinctive and important task and supervisor as highly identifiable social context to test de SSMMD. 


\section{Method}

\section{Participants}

Participants were 331 students (69\% female) in the last year of their studies at a French speaking Belgian University. The average age was $24(S D=5.45$; minimum $=21$, maximum $=54)$. Participants were attending a variety of graduate programs: psychology $(\mathrm{N}=$ $110)$, education $(\mathrm{N}=31)$, physiotherapy $(\mathrm{N}=46)$, economy $(\mathrm{N}=82)$, and speech therapy ( $\mathrm{N}$ $=62$ ). Most Belgian university programs are organized around the successful completion of five successive academic years, leading to the award of a master's degree. In the last year of their program, students have to complete a final graduate dissertation, which counts for a large proportion (about 50\%) of their final assessment.

\section{Measures}

The questionnaire was constructed on the basis of existing scales that were adapted to the task targeted by this study, namely final graduate dissertation. French versions of most of these scales had been used in previous research, showing adequate reliability and validity (Dupont et al., 2013; Galand, Raucent, \& Frenay, 2010; Galand \& Frenay, 2005). Unless otherwise noted, the items were scored on a five-point Likert scale ranging from 1 (strongly disagree) to 5 (strongly agree).

\section{Perceived social context}

Participants assessed the support they experienced from their supervisor. The items were adapted from measures developed by Skinner and Belmont (1993) and by Galand and Philippot (2005).

Autonomy-support. Three items $(\alpha=.74)$ tapped the students' perception of autonomysupport from their supervisor, including dedication of autonomy and provision of choice (e.g., "My supervisor takes my ideas into account"; "My supervisor lets me work freely on the final dissertation").

Structure. Four items $(\alpha=.81)$ tapped the students' perception of the structure provided by their supervisor, including dedications of resources and useful information (e.g., "My supervisor gives me useful information concerning the required methodology"; "My supervisor helps me to structure my work").

Involvement. Four items $(\alpha=.88)$ tapped the students' perception of involvement from their supervisor, including pedagogical caring behavior (e.g., "In general, I have a good rela- 
tionship with my supervisor"; "My supervisor tries to make me comfortable to ask questions").

\section{Students'self-perceptions}

Perceived competence. Participants assessed their own confidence in their ability to succeed in the various tasks required to complete the final dissertation (FD) within the time limit. Six items $(\alpha=.75)$ were adapted from Galand and Philippot (2002) and followed the recommendations from Bandura (1997) concerning the measurement of self-efficacy in specific contexts as items referred to the final dissertation. The items included among others "I feel confident about writing my FD”.

Perceived autonomy. Participants assessed their feelings of self-determination while they were working on the final dissertation. Six items $(\alpha=.88)$ were adapted from measure developed by Sheldon, Ryan, Deci and Kasser (2004) and Ryan and Connell (1989). Example item on this scale is "I invest myself in the FD because I take great pleasure working on it".

Perceived relatedness. Participants assessed their sense of belongingness toward the university. This scale included a set of three items $(\alpha=.76)$ adapted from Hausmann and colleagues (2007). Example item: "I feel like I belong to this University".

\section{Engagement}

Emotional engagement. This scale assessed the emotions that the participants felt while they were working on their FD. The two items $(\alpha=.78)$ were adapted from Galand and Philippot (2005) and assessed negative emotions (e.g. "I feel anxious about my FD"). The score of this scale was reversed.

Cognitive engagement. The deep-processing-strategies scale comprised three items ( $\alpha$ $=.65$ ) adapted from previous studies (Galand et al., 2010), such as "I have a critical attitude towards the literature I read for my FD".

Behavioral engagement. This scale was adapted from Skinner, Kindermann and Furrer (2009), to measure behavioral involvement in the completion of the FD. Three items $(\alpha=.75)$ tapped the students' effort and the time spent on the FD (e.g. "I have already put a lot of effort into my FD").

\section{Procedure}

A questionnaire was administered during lecture time in the spring. At this time, the students had already been working on their final dissertation for several months. The deadline 
for completing the final dissertation is at the end of August. All the students attending the lecture were informed of the aim and method of the study; their participation was voluntary.

Analytical strategy and data analysis

\section{Analytical strategy}

Structural Equation Models (SEM) have been used to analyze the above effects, because they allow including in the same model multiple dependent variables, reducing measurement error by having multiple indicators per latent variables, and testing a full theoretical model (Garson, 2008). In addition, it allows testing the unique contribution of indicators of the social context and self-perceptions on different dimensions of student engagement by controlling for the impact of other independent variables.

First, we tested the SSMMD in its entirety. This model specified paths from autonomy support to perceived autonomy, from structure to perceived competence, and from involvement to perceived relatedness. Turning to the relations between self-perceptions and student engagement, we expected that perceived competence, autonomy and relatedness will be associated with emotional, cognitive and behavioral engagement, in line with the SSMMD. The initial model was compared to a more parsimonious one, in which all the non-significant paths were deleted one at a time. After that, two alternative models were tested. One based on six crossed paths between the students' perception of supervisor's behaviors and selfperceptions variables to the initial SSMMD; the other tested direct associations between the three dimensions of both the students' perception of the supervisor's behaviors and the engagement variables. Last, we tested the indirect effects of the three dimensions of the social context on the three components of student engagement.

\section{Data analyses}

We conducted measurement and structural analyses using Amos (Version 16) and the maximum-likelihood estimation method. To assess model fit, we used well-established indices, such as the comparative fit index (CFI), and the root-mean-square error of approximation (RMSEA), as well as the chi-square test statistics. For the CFI indices, values greater than .90 are typically considered as being acceptable, and values greater than .95 indicate good fit to the data (Byrne, 2001). For well-specified models, an RMSEA of .06 or less reflects a good fit (Hu \& Bentler, 1999). As a part of the structural model, we also statistically tested the pro- 
posed indirect effects. The significance of these indirect effects was determined by bootstrap methods using 95\% confidence intervals (Mallinckrodt, Abraham, Wei \& Russel, 2006). Amos calculates confidence intervals for total indirect effects using the unstandardized mean beta weight and the associated standard error from 1000 bootstrap samples (Shrout \& Bolger, 2002). The indirect effect is considered significant if the confidence interval does not include zero.

\section{Results}

Step 1: Measurement model

First, as some constructs contained six items, we used parceling for the perceived competence and the perceived autonomy constructs. This technique allowed us to estimate fewer parameters, improve the model fit, and reduce bias in the estimation of the structural parameters (Bandalos, 2002).These scales had high internal reliability and the exploratory factor analyses demonstrated unidimensionality by yielding single factors unidimensionality is a requirement for parceling (Bandalos, 2002). The most highly correlated items - corresponding to the competence and the autonomy constructs — were parceled into three composite items for each of these two scales.

Then all the items were entered into the same measurement model. The hypothesized model displayed an adequate fit to the data: $\chi^{2}(340, \mathrm{~N}=331)=718.98, p<.001 ;$ RMSEA $=.06 ; C F I=.92$ ). Factor loadings were quite high (ranging from .55 to .89 ) apart from the third indicator of behavioral engagement (.31). We observed the modification indices. They suggested adding covariance between the error terms of two items assessing the students' perception of autonomy-supportive behaviors from supervisor as well as between the error terms of two items assessing the students' perception of involved behaviors from supervisor. As these errors terms corresponded to the same latent variables, adding their covariance was not considered to be problematic. Again a CFA was performed. The results indicated an adequate model fit $\left(\chi^{2}(312, \mathrm{~N}=331)=570.96, p<.001 ; R M S E A=.05 ; C F I=.94\right)$. Descriptive statistics for all the measures are presented in Table 1 . All the variables had adequate statistical characteristics. 
Table 1. Descriptive Statistics for all the Latent Variables

\begin{tabular}{lcccc}
\hline Variables & Range & $M$ & $S D$ & Cronbach's alpha \\
\hline Social context & & & & \\
1. Involvement & $1-5$ & 3.99 & .83 & .88 \\
2. Structure & $1-5$ & 3.51 & .94 & .81 \\
3. Autonomy-support & $1-5$ & 4.29 & .67 & .74 \\
Self-perceptions & & & & \\
4. Competence & $1-5$ & 3.81 & .61 & .75 \\
5. Relatedness & $1-5$ & 3.79 & .69 & .76 \\
6. Autonomy & $1-5$ & 3.73 & .73 & .88 \\
Engagement & & & & .75 \\
7. Behavioral & $1-5$ & 4.13 & .81 & .65 \\
8. Cognitive & $1-5$ & 3.67 & .75 & .78 \\
9. Emotional & $1-5$ & 3.87 & 1.03 & \\
\hline
\end{tabular}

Note. $N=331$

The correlations among the latent variables are presented in Table 2. Results suggested no problems of multicollinearity. The three supervisors' behaviors were correlated with each other (Reeve \& Halusic, 2009; Sierens et al., 2009), as were the self-perceptions and the components of engagement. These associations underscore the important to consider these variables all together to isolate 'true' independent effects. 
Table 2.-Zero-Order Correlations Among Variables in the Measurement Model

\begin{tabular}{|c|c|c|c|c|c|c|c|c|c|}
\hline & 1 & 2 & 3 & 4 & 5 & 6 & 7 & 8 & 9 \\
\hline \multicolumn{10}{|l|}{ Social context } \\
\hline 1. Involvement & - & & & & & & & & \\
\hline 2. Structure & $.70 * *$ & - & & & & & & & \\
\hline 3. Autonomy-support & $.66^{* *}$ & $.47 * *$ & - & & & & & & \\
\hline \multicolumn{10}{|l|}{ Self-perceptions } \\
\hline 4. Competence & $.38 * *$ & $.38 * *$ & $.38 * *$ & - & & & & & \\
\hline 5. Relatedness & $.23 * *$ & $.13^{*}$ & $.23 * *$ & $.23 * *$ & - & & & & \\
\hline 6. Autonomy & $.32 * *$ & $.22 * *$ & $.32 * *$ & $.48 * *$ & $.47 * *$ & - & & & \\
\hline \multicolumn{10}{|l|}{ Engagement } \\
\hline 7. Behavioral & -.01 & .01 & -.06 & $.27 * *$ & .03 & .09 & - & & \\
\hline 8. Cognitive & $.26 * *$ & $.22 * *$ & $.31 * *$ & $.42 * *$ & $.46^{* *}$ & $.44 * *$ & .08 & - & \\
\hline 9. Emotional & $.12 *$ & -.03 & $.15^{* *}$ & $.40 * *$ & -.04 & $.09 *$ & $.12 *$ & $-.12 *$ & - \\
\hline
\end{tabular}

Note. $N=331 ; * p<.05 ; * * p<.001$

\section{Step 2: Structural Modeling}

The second step of the analysis included a test of SSMMD (see figure 1). In this model, we allowed free estimation of the covariance between the three exogenous latent variables (perceived autonomy-support, structure, and involvement from supervisor) and of the covariance of the structural residuals among the three students' self-perceptions which had been found to be related in the correlation analysis (Table 2). Ryan and Deci (2000) proposed that autonomy, competence and relatedness were interrelated. Results showed that the hypothesized covariance structure displayed an adequate fit to the data, $\chi^{2}(330, N=331)=627.97, p<$ $.001, C F I=.93, R M S E A=.05$. Then we tested alternative models in which the lowest standardized coefficients were deleted one at a time until only significant paths remained in the model. This first final alternative model resulted in an adequate fit, $\chi^{2}(334, N=331)=629.31$, 
$p<.001, C F I=.93, R M S E A=.05$. The chi-square difference test between the two models was non-significant, $\chi^{2}(4)=1.34 p>.1$. We kept this alternative model on the grounds of parsimony. Figure 2 presents all the standardized significant path coefficients.

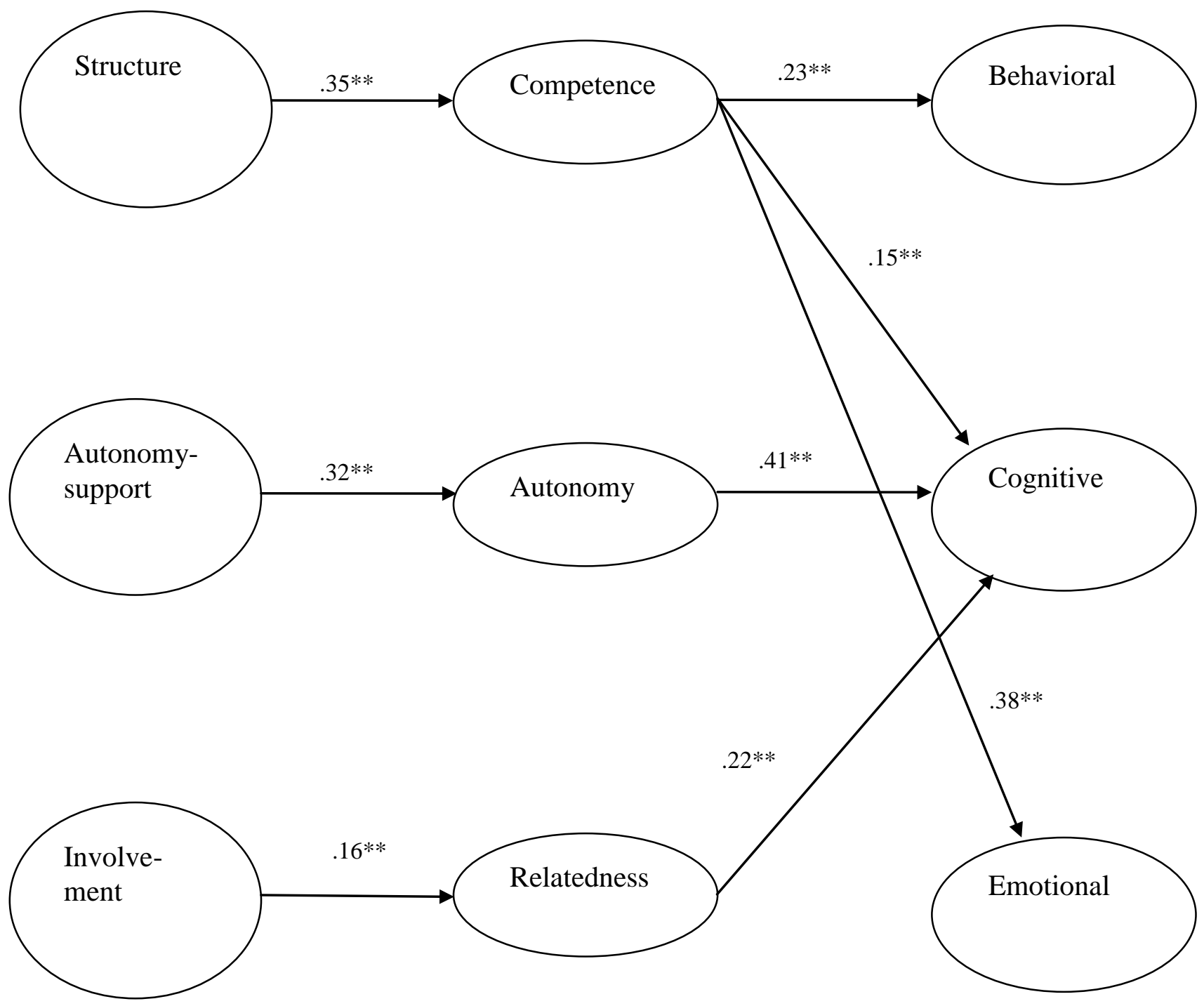

Figure 2. Associations between the social context, self-perceptions and engagement variables.. All the path coefficients included are standardized. ${ }^{*} \mathbf{p}<.05 ; * * \mathbf{p}<.001$ 
The results indicate that autonomy-support was associated with perceived autonomy ( $\beta$ $=.32, p<.001)$, structure with perceived competence $(\beta=.35, p<.001)$, and involvement with perceived relatedness $(\beta=.16, p<.05)$. In addition, perceived competence was associated with emotional $(\beta=.38, p<.001)$, cognitive $(\beta=.15, p<.05)$, and behavioral engagement $(\beta=$ $.23, p<.001)$. Perceived relatedness $(\beta=.22, p<.001)$ and autonomy $(\beta=.41, p<.001)$ were also associated with cognitive engagement. However, perceived autonomy and relatedness were not associated with emotional and behavioral engagement.

\section{Step 3: Alternative models}

In order to assess the specific contribution of each dimension of social context on the self-perceptions variables, we tested an alternative model that posited direct relationships between each dimension of the social context and the three self-perceptions variables ( 6 crossed paths were added to the first alternative model). This model resulted in an adequate fit, $\chi^{2}$ $(328, N=331)=611, p<.001, C F I=.93, R M S E A=.05$. The results indicated that autonomy supportive supervisor was associated with perceived autonomy $(\beta=.38, \mathrm{p}<.001)$ and competence $(\beta=.27, \mathrm{p}<.001)$, that involved supervisor was associated with relatedness $(\beta=.18, p<$ $.05)$, and that structured supervisor was associated with perceived competence $(\beta=.21, p<$ $.05)$. However, the chi-square difference test between this model and the first alternative model was non-significant, $\chi^{2}(6)=18.31, p>.10$. So we considered that the first alternative model was more adequate on the grounds of parsimony.

Finally, in order to assess the partial or full mediation hypothesis of the selfperceptions, we added nine supplementary paths between the supervisor's behaviors and the three dimensions of student engagement to the first alternative model. This model resulted in an adequate fit, $\chi^{2}(325, \mathrm{~N}=331)=615.6, p<.001, C F I=.93, R M S E A=.05$. None of the paths between social context and engagement variables were significant and the chi-square difference between this model and the first alternative model was non-significant, $\chi^{2}(9)=$ $13.71, p>.10$. So, on the grounds of parsimony, we kept the first alternative model.

\section{Step 4: Indirect effects}

The analyses of the indirect effects of the students' perception of the supervisor's behaviors on emotional, cognitive and behavioral engagement were based on the final model (see Figure 2). Results indicated that autonomy-support had a positive effect on cognitive en- 
gagement through perceived autonomy $(\beta=.14$, BC 95\% CI =.06, .26). In addition, structure had a positive effect on both emotional and behavioral engagement through perceived competence $(\beta=.13, \mathrm{BC} 95 \% C I=.08, .20 ; \beta=.08, \mathrm{BC} 95 \% C I=.04, .14)$. Involvement had no significant effect on any component of engagement.

\section{Discussion}

The main goal of the present study was to test the SSMMD in its entirety, including at the same time the students' perceptions of supervisors' behaviors, their self-perceptions, and the three dimensions of student engagement. Two underlying assumptions of the SSMMD (and more broadly of the SDT) were supported by the results of this study - the three dimensions of social context have specific effects on self-perception variables and these perceptions are mediators of the relationship between context and student engagement - one was not- the three self-perception variables do not have a direct impact on the dimensions of student engagement. In the following of this section each research question raised will be addressed and provided with a (tentative) reply based on the present results.

Research question 1: What are the associations between the students'perception of the supervisor's behaviors and the self-perception variables?

As regards the social context, results revealed that the supervisor has an important role for the development of positive students' self-perceptions. The present study confirms theoretical assumptions of the SSMMD (Skinner \& Belmont, 1993; Skinner et al., 2008): students experienced competence when they perceived structured behaviors from their supervisor, autonomy when they perceived autonomy-supportive behaviors from their supervisor, and relatedness when they perceived involved behaviors from her/him. In addition, it appeared that adding the crossed associations between the supervisor's behaviors and the self-perceptions variables into the model did not lead to a better fit, thus indicating that the SSMMD assumptions should be kept.

Research question 2: What are the associations between the self-perception variables and the three dimensions of student engagement?

In line with several empirical studies grounded in the SSMMD perspective (Connell, Spencer \&Aber, 1994; Furrer and Skinner, 2003; Skinner et al., 2008), present results revealed that self-perception variables are important for optimal behavioral, cognitive and emotional engagement. A clear contributor to students' cognitive, behavioral and emotional en- 
gagement was their perceived competence: in line with Bandura (1997), students who perceived themselves as competent were more likely to employ effort and to use deep processing strategies when faced with the final dissertation; moreover they were less likely to express negative emotions. Students' perceived autonomy made the strongest contribution to cognitive engagement, thus students who felt self-determined used deeper processing strategies. However, in contrast with our hypotheses, perceived autonomy was not associated with emotional nor with behavioral engagement. Actually results in the literature on the same topic are inconsistent: Skinner and Belmont (1993) failed to document a link between perceived autonomy and behavioral and emotional engagement, while Skinner and colleagues (2008) found positive significant associations. A possible interpretation of these results is that perceived autonomy alone is not sufficient to elicit behavioral engagement (Higgins \& Kruglanski, 2000).

Furthermore, intercorrelations analyses (see table 2) showed that perceived autonomy is related with emotional engagement but this effect disappears in the structural equation analyses, thus suggesting that a mediator is involved that should explain the initial relationship between these two variables. Based on the significant correlations between perceived competence with both perceived autonomy and emotional engagement, we suggest that it might be the mediator. This proposal is also supported at the theoretical level (Bandura, 1986; 1997; Pajares, 1996). If this hypothesis is confirmed, then it would call into question the structure of SSMMD, placing perceived competence between perceived autonomy and emotional engagement. Nonetheless, we wish future research will address these questions.

Finally, the students' perception of belongingness was associated with cognitive engagement, thereby confirming findings from Baumeister and colleagues (2002)'s that social exclusion reduces the use of deep-processing strategies. However, perceived relatedness was not associated with emotional nor with behavioral engagement, which contradicts results from Tinto $(1997,2001)$, who found that the student's identification with the college was an important predictor of emotional and behavioral engagement among first-year university students. The author argued that this identification was particularly important because of the transition from high school to college. Since in our study students are in their last year of the university, they have already successfully achieved the four precedent years, and hence feel presumably already adapted to the institution. Consequently, it is possible that this identification with the institution has become less important in eliciting behavioral and emotional engagement. 
Research question 3: what are the direct and indirect associations between the students' perceptions of the supervisor's behaviors and the engagement variables?

Results of the last alternative model indicated that no-one direct paths between the students' perceptions of the supervisor's behaviors and the dimensions of student engagement were significant. In other words, these effects were totally explained by the self-perceptions variables. This indicates that self-perceptions variables are the most proximal predictors of emotional, cognitive and behavioral engagement, in line with the suggestion of Skinner and colleagues (2008). However, these results are in contrast with the Skinner and Belmont (1993)'s study, which showed that children's behavioral engagement was primary a function of the student perception of teacher structure, and emotional engagement was predicted by teacher involvement. It should be noted, though, that these studies did not consider selfperception variables as mediators. This suggests the importance of considering at the same time variables related to the social context, the self and the engagement in a multidimensional approach, so as to understand the specific pathways that can lead to the different dimensions of student engagement.

In this perspective, an autonomy supportive supervisor was related to perceived autonomy, which in turn was associated with cognitive engagement. This result is congruent with the experimental studies of Vansteenkiste and his colleagues (2004). In addition, structured behaviors from supervisor were associated with perceived competence, which in turn was associated with both emotional and behavioral engagement. These results are important as they show the importance of considering different type of teacher/supervisor behaviors and dimensions of student engagements; they indicate that specific supervisor's behaviors have specific indirect effect, through different self-perception variables, on emotional, cognitive and behavioral engagement.

Unexpectedly, involved behaviors from supervisor had no direct or indirect effects on student engagement. These results are contrary to other studies conducted in school contexts (Birch \& Ladd, 1997; Furrer \& Skinner, 2003; Wentzel, 1997). They may be due to the context in which data were gathered. Indeed, some authors have suggested that the processes leading to student engagement might be different in less constrained contexts (Blumenfeld, 1992; Fredricks et al., 2004; Pintrich, 2003). High school students learn in a constrained environment, as they are under legal obligation, class attendance is compulsory, and topics and 
programs are externally determined. In contrast, graduate students working on their final dissertation learn in a more autonomous and less structured environment. In this autonomous context, we may hypothesize that involved behaviors from supervisors have less importance to elicit student engagement because student have less contacts with them and are also less dependent than in high school. This result suggests that the context may change the force and the direction of the relationships between the social actors and individuals' self-perceptions (Brofenbrenner, 2005).

\section{Limitations}

Two principal limits of our study should be noted. First, our results are based on correlational data, which does not allow us to infer causal relationships among the variables in our model. Although the model we tested was strongly based on the theoretical propositions postulated by the SSMMD, longitudinal design involving data collection at multiple points in time is necessary to provide more robust confirmation of the present results. In addition, such methodology will facilitate the investigation of dynamics between the supervisor's behaviors and student engagement. Consistent with that, a study by Skinner and colleagues (2008) showed that the level of student engagement in a learning task modified by itself the extent to which the teacher interacted with the student and the quality of this interaction.

Second, all constructs were measured by means of self-reporting scales. Although we believe students reports to be highly valid sources of information, the inclusion of other sources of information in the future might strengthen the observed patterns. For example, valid sources of data could be the supervisors' reports of how they interact with the students realizing their final dissertation, as well as supervisors' ratings of all forms of engagement.

\section{Theoretical contribution to the SSMMD}

Understanding the processes underlying student engagement allows intervening effectively to increase student engagement. This understanding is particularly important as student engagement is a proximal predictor of many important outcomes: grades and achievement (Furrer\& Skinner, 2003; Reeve et al., 2004), persistence (Appleton et al., 2006), well-being (Brault-Lobé \& Dubé, 2010), dropping out prevention (Archambault et al., 2009) and timely completion of the final graduate dissertation (Dupont et al., 2013). In view of our results, some of the assumptions of SSMMD were confirmed: the three dimensions of social context have specific effects on self-perception variables, these perceptions are mediators of the rela- 
tionship between context and student engagement; others have not been confirmed: the three self-perception variables do not have a direct impact on the dimensions of student engagement. We suggested that the context may moderate the intensity and strength of the relationship between the self-perceptions and student engagement and that perceived competence might potentially be a mediator of the relationship between perceived autonomy and emotional engagement. To conclude, new studies using similar analytic approaches are needed to clarify the theoretical assumptions of SSMMD.

\section{References}

Appleton, J. J., Christenson, S. L., \& Furlong, M. J. (2008). Student engagement with school: Critical conceptual and methodological issues of the construct. Psychology in the Schools, 45, 369-386. doi:10.1002/pits.20303

Appleton, J. J., Christenson, S. L., Kim, D., \& Reschly, A. L. (2006). Measuring cognitive and psychological engagement: Validation of the Student Engagement Instrument. Journal of School Psychology, 44, 427 - 445. doi:10.1016/j.jsp.2006.04.002

Archambault, I., Janosz, M., Fallu, J.-S., \& Pagani, L. S. (2009). Student engagement and its relationship with early high school dropout. Journal of Adolescence, 32(3), 651-670. doi: 10.1016/j.adolescence.2008.06.007

Bandalos, D. L. (2002). The effects of item parceling on goodness-of-fit and parameter estimate bias in structural equation modeling. Structural Equation Modeling, 9, 78102.:10.1207/S15328007SEM0901_5

Bandura, A. (1991). Social cognitive theory of self-regulation. Organizational Behavior and human Decision Processes, 50, 248-287. doi:10.1016/0749-5978(91)90022-L

Bandura, A. (1997). Self-efficacy: The Exercise of Control. New-York: Freeman.

Baumeister, R. F., \& Leary, M. R. (1995). The need to belong: Desire for interpersonal attachments as a fundamental human motivation. Psychological Bulletin, 117, 497-529. doi:10.1037/0033-2909.117.3.497

Baumeister, R. F., Twenge, J. M., \& Nuss, C. K. (2002). Effects of social exclusion on cognitive processes: Anticipated aloneness reduces intelligent thought. Journal of Personality and Social Psychology, 83, 817-827. doi: 10.1037/0022-3514.83.4.817

Benware, C., \& Deci, E. L. (1984). Quality of learning with an active versus passive motivational set. American Educational Research Journal, 21, 755-765. doi: 10.3102/00028312021004755

Bowlby, J. (1969/1973). Attachment and loss. Vols. 1 and 2. New York: Basic Books 
Blumenfeld P. C. (1992). Classroom learning and motivation: clarifying and expanding goal theory. Journal of Educational Psychology, 84, 272- 281. doi:10.1037/00220663.84.3.272

Birch, S. H., \& Ladd, G. W. (1997). The teacher-child relationship and children's early school adjustment. Journal of School Psychology, 35, 61-79. doi: 10.1016/S00224405(96)00029-5

Brault-Labbé, A., Dubé, L. (2010). Engagement scolaire, bien-être personnel et autodétermination chez des étudiants à l'université. / School engagement, personal well-being and self-determination in university students. Canadian Journal of Behavioural Science/Revue canadienne des sciences du comportement, 42 (2), 80-92.

doi: $10.1037 / \mathrm{a} 0017385$

Byrne, B. M. (2001). Structural equation modeling with AMOS: Basic concepts, applications, and programming. Mahwah, NJ: Lawrence Erlbaum Associates. doi: 10.1207/S15327574IJT0101_4

Christenson, S.L., Reschly, A.L., \& Wylie, C. (Eds.). (2012). The handbook of research on student engagement. New York: Springer.

Connell, J. P., \& Wellborn, J. G. (1991). Competence, autonomy, and relatedness: A motivational analysis of self-system processes. In M. R. Gunnar \& L. A. Sroufe (Eds.), Selfprocesses and development (Vol. 23, pp. 43 - 77). Hillsdale, NJ: Lawrence Erlbaum.

Deci, E.L., Ryan, R.M. (2000) The "what" and "why" of goal pursuits: Human needs and the self-determination of behavior. Psychological Inquiry, 11, 227-268. doi:10.1207/S15327965PLI1104_01

Dupont, S., Meert, G., Galand, B. \& Nils, F. (2013). Postponement in the completion of the final dissertation: An Underexplored Dimension of Achievement in Higher Education. European Journal of Educational Psychology, 28(3), 619-639. doi:10.1007/s10212-012$0132-7$

Finn, J. D., Pannozzo, G. M., \& Voelkl, K. E. (1995). Disruptive and inattentive-withdrawn behavior and achievement among fourth graders. Elementary School Journal, 95, 421454.

Fredricks, J. A., Blumenfeld, P. C., \& Paris, A. H. (2004). School engagement: potential of the concept, state of the evidence. Review of Educational Research, 74, 59-109. doi: $10.3102 / 00346543074001059$ 
Furrer, C., \& Skinner, E. (2003). Sense of relatedness as a factor in children's academic engagement and performance. Journal of Educational Psychology, 95, 148-162. doi: 10.1037/0022-0663.95.1.148 .

Gaertner, S. L., \& Dovidio J. F. (2000). Reducing Intergroup Bias: The Common Ingroup Identity Model. Philadelphia, PA: Psychology Press

Galand, B., \& Frenay M. (2005). L'approche par problèmes et par projets dans l'enseignement supérieur : Impact, enjeux et défis [The Problem Solving and Project Approach in Higher Education: Impact, Stakes and Challenges], Louvain-la-Neuve, Presses Universitaires de Louvain.

Galand B., \& Philippot P. (2002). Style motivationnel des élèves du secondaire : Développement d'un instrument de mesure et relations avec d'autres variables pédagogiques. Canadian Journal of Behavioral Science, 34, 261-275. doi: 10.1037/h0087179

Galand B., \& Philippot P. (2005). L'école telle qu'ils la voient : Validation d'une mesure des perceptions du contexte scolaire par les élèves du secondaire. Canadian Journal of Behavioral Science, 37, 138-154. doi: 10.1037/h0087251

Galand, B., Raucent, B., \& Frenay, M. (2010). Engineering students' self-regulation, study strategies, and motivational believes in traditional and problem-based curricula. International Journal of Engineering, 26, 523-534.

Garson, G. D. (2008). Structural equation modeling, from statnotes: Topics in multivariate analysis. Retrieved from http://faculty.chass.ncsu.edu/garson/pa765/statnote.htm

Goodenow, C. (1993). Classroom belonging among early adolescent students: Relationships to motivation and achievement. Journal of Early Adolescence, 13, 21- 43 doi: $10.1177 / 0272431693013001002$

Greene, B. A., Miller, R. B., Crowson M., Duke B., \& Akey K. (2004). Predicting high school students' cognitive engagement and achievement: contributions of classroom perceptions and motivation. Contemporary Educational Psychology, 29, 499-517.

http://dx.doi.org/10.1016/j.cedpsych.2004.01.006

Hausmann, L. R. M., Schofield, J. W., \& Woods, R. L. (2007). Sense of belonging as a predictor of intentions to persist among African American and White first year college students. Research in Higher Education, 48(7), 803-839. doi : 10.1007/s11162-007-9052-9

Hu, L., \& Bentler, P. M. (1999). Cutoff criteria for fit indexes in covariance structure analysis: Conventional criteria versus new alternatives. Structural Equation Modeling, 6, 1-55. doi: 10.1080/10705519909540118 
Koestner, R., Losier, G. F., Vallerand, R. J., \& Carducci, D. (1996). Identified and introjected forms of political internalization: extending self-determination theory. Journal of Personality and Social Psychology, 70, 1025-1036. doi: 10.1037/0022-3514.70.5.1025

Lam S., Wong B. R., Yang H., Liu Y (2012). Understanding Student Engagement with a Contextual Model. In Ed. S. Christenson (Ed.). Handbook of Research on Student Engagement (pp.403-419). New York: Springer. doi : 10.1007/978-1-4614-2018-7_19

Mallinckrodt, B., Abraham, W. T., Wei, M., \& Russell, D. W. (2006). Advances in testing the statistical significance of mediation effects. Journal of Counseling Psychology, 53, 372378. doi:10.1037/0022-0167.53.3.372

Marton, F., \& Säljö, R. (1997). Approaches to learning. In F. Marton, D. J. Hounsell, \& N. J. Entwistle (Eds.), The Experience of Learning (pp. 39- 8). Edinburgh: Scottish Academic Press ( 2nd ed.)

Miller, R. B., Greene, B. A., Montalvo, G. P., Ravindran, B., \& Nichols, J. D. (1996). Engagement in academic work: the role of learning goals, future consequences, pleasing others, and perceived ability. Contemporary Educational Psychology, 21, 388-422. http://dx.doi.org/10.1006/ceps.1996.0028

Murray, C., \& Greenberg, M. T. (2000). Children's relationships with teachers and bonds with school: An investigation of patterns and correlates in middle childhood. Journal of School Psychology, 38(5), 423-445. http://dx.doi.org/10.1016/S0022-4405(00)00034-0

Pekrun, R. (2006). The control-value theory of achievement emotions: assumptions, corrolaies and implications for educational research and practice. Educational Psychological Review, 18, 315-341. doi: 10.1007/s10648-006-9029-9

Phan, H.P. (2007). Examination of student learning approaches, reflective thinking, and selfefficacy beliefs at the University of the South Pacific: A path analysis. Educational Psychology, 27(6), 789-806. doi: 10.1080/01443410701349809

Phan, H.P. (2009). Exploring students' reflective thinking practice, deep processing strategies, effort, and achievement goal orientations. Educational Psychology, 29(3), 297-313. doi: $10.1080 / 01443410902877988$

Pintrich, P. R., \& De Groot, E. V. (1990). Motivational and self-regulated learning components of classroom academic performance. Journal of Educational Psychology, 82(1), 3340. doi: 10.1037/0022-0663.82.1.33

Pintrich, P. R. (2003). A motivational science perspective on the role of student motivation in learning and teaching contexts. Journal of Educational Psychology, 95, 667-686. doi: 10.1037/0022-0663.95.4.667 
Reeve, J. (2002). Self-determination theory applied to educational settings. In E.L. Deci \& R.M. Ryan (Ed.), Handbook of Self-Determination Research (pp. 246- 274). Rochester, NY: The University of Rochester Press.

Reeve, J. (2012). A Self-determination Theory Perspective on Student Engagement. In Sandra Christenson (Ed.), Handbook of Research on Student Engagement (pp 149-172.). New York: Springer, 2012. doi: 10.1007/978-1-4614-2018-7_7

Reeve, J., \& Halusic, M. (2009). How k-12 teachers can put self-determination theory principles into practice. Theory and Research in Education, 7, 145-15. doi: $10.1177 / 1477878509104319$

Reeve, J., Jang, H., Carrell, D., Jeon, S., \& Barch, J. (2004). Enhancing students' engagement by increasing teachers' autonomy support. Motivation and Emotion, 28, 147-169. doi: 10.1023/B:MOEM.0000032312.95499.6f

Robbins, S. B., Lauver, K., Le, H., Davis, D., Langley, R., \& Carlstrom, A. (2004). Do psychosocial and study skill factors predict college outcomes? A meta-analysis. Psychological Bulletin, 130(2), 261-288. doi: 10.1037/0033-2909.130.2.261

Roeser, R. W., Midgley, C., \& Urdan, T. C. (1996). Perceptions of the school psychological environment and early adolescents' psychological and behavioral functioning in school: The mediating role of goals and belonging. Journal of Educational Psychology, 88, 408422. doi: 10.1037/0022-0663.88.3.408

Ryan, R. M., \& Deci, E. L. (2008). A self-determination theory approach to psychotherapy: the motivational basis for effective change. Canadian Psychology, 49, 186-193. doi: $10.1037 / \mathrm{a} 0012801$

Ryan, R. M., \& Grolnick, W. S. (1986). Origins and pawns in the classroom: Self-report and projective assessments of individual differences in children's perceptions. Journal of Personality and Social Psychology, 50 (3), 550- 558. doi: 10.1037/0022-3514.50.3.550

Schunk, D. H., Pintrich, P. R., \& Meece, J. L. (2008). Motivation in Education: Theory, Research and Applications (3rd ed.). Upper Saddle River, NJ: Merill-Pentrice Hall.

Sheldon, K. M., \& Bettencourt, B. A. (2002). Psychological need-satisfaction and subjective well-being within social groups. British Journal of Social Psychology, 41, 25-38. DOI: $10.1348 / 014466602165036$

Sheldon, K. M., Ryan, R. M., Deci, E. L., \& Kasser, T. (2004). The independent effects of goal contents and motives in well-being: It's both what you pursue and why you pursue it. Personality and Social Psychology Bulletin, 30, 475-486. doi: $10.1177 / 0146167203261883$ 
Shrout, P. E., \& Bolger, N. (2002). Mediation in experimental and non experimental studies: New procedures and recommendations. Psychological Methods, 7, 422-445. doi: 10.1037/1082-989X.7.4.422

Sierens, E., Vansteenkiste, M., Goossens, L., Soenens, B., \& Dochy, R. (2009). The synergistic relationship of perceived autonomy support and structure in the prediction of selfregulated learning. British Journal of Educational Psychology, 79, 57-6. doi: 10.1348/000709908X304398

Sinclair, M. F., Christenson, S. L., Lehr, C. A., \& Anderson, A. R. (2003). Facilitating school engagement: Lessons learned from Check \& Connect longitudinal studies. California School Psychologist, 8, 29 - 41. doi :10.1007/BF03340894

Skinner, E. A., \& Belmont, M. J. (1993). Motivation in the classroom: reciprocal effects of teacher behavior and student engagement across the school year. Journal of Educational Psychology, 85, 571-581. doi: 10.1037/0022-0663.85.4.571

Skinner, E., Furrer, C., Marchand, G., \& Kindermann, T. (2008). Engagement and disaffection in the classroom: part of a larger motivational dynamic? Journal of Educational Psychology, 100(4), 765-781. doi: 10.1037/a0012840

Skinner, E. A., Wellborn, J. G., \& Connell, J. P. (1990). What it takes to do well in school and whether I've got it: A process model of perceived control and children's engagement and achievement in school. Journal of Educational Psychology, 82, 22 - 32. doi: $10.1037 / 0022-0663.82 .1 .22$

Skinner, E. A., Zimmer-Gembeck, M., \& Connell, J. (1998). Individual differences and the development of perceived control. Monographs of the Society for Research in Child Development, 63(2-3, Serial No. 254). doi: 10.2307/1166220

Tinto, V. (1997). Classrooms as communities: exploring the educational character of student persistence. Journal of Higher Education, 68(6), 599-623.

Tinto, V. (2001). Rethinking the First Year of College. Higher Education Monograph Series, Syracuse University.

Vansteenkiste, M., Simons, J., Lens, W., Sheldon, K. M., \& Deci, E. L. (2004). Motivating learning, performance, and persistence: The synergistic effects of intrinsic goal contents and autonomy-supportive contexts. Journal of Personality and Social Psychology, 87, 246 - 260. doi: 10.1037/0022-3514.87.2.246

Vansteenkiste, M., Simons, J., Lens, W., Soenens, B., \& Matos, L. (2005). Examining the impact of extrinsic versus intrinsic goal framing and internally controlling versus autonomy- 
supportive communication style upon early adolescents' academic achievement. Child Development, 76, 483-501. doi: 10.1111/j.1467-8624.2005.00858.x

Wentzel, K. (1997). Student motivation in middle school: The role of perceived pedagogical caring. Journal of Educational Psychology, 89, 411-419. doi:10.1037/00220663.89.3.411

Wigfield, A., Eccles, J. S., Schiefele, U., Roeser, R., \& Davis-Kean, P. (2006). Development of achievement motivation. In W. Damon (Series Ed.) \& N. Eisenberg (Vol. Ed.) Handbook of child psychology (6th Ed., Vol. 3, pp.). Hoboken, NJ: Wiley.

Williams, G. C., \& Deci, E. L. (1996). Internalization of biopsychosocial values by medicalstudents: A test of self-determination theory. Journal of Personality and Social Psychology, 70, 767-779. doi: 10.1037/0022-3514.70.4.767 